\title{
IMPACT OF REPLACING EGG YOLK WITH LECITHIN ON SPERM CHARACTERISTICS, BACTERIAL COUNT AND FERTILIZING ABILITY OF CRYOPRESERVED BUFFALO SEMEN.
}

El-Sherbieny, M.A.

Animal Production Research Institute, Agricultural Research Center, Egypt.

\begin{abstract}
Soy bean lecithin has been used to replace egg yolk in the semen extender. The aim of this study was to evaluate the effect of replacing egg yolk by soy-lecithin in tris extender on freezability and fertilizing capacity of buffalo semen. Semen from five buffalo bulls was frozen in tris extender containing $0.5,1.0$ and $2 \%$ soy-lecithin (treatments) or $15 \%$ egg yolk (control). Percentage of motility, livability and intact acrosome spermatozoa and also bacterial count was assessed in diluted, postequilibrated and post-thawed semen. Results revealed insignificant differences in percentage of sperm motility in diluted semen. However, percentages of sperm motility, livability and intact acrosome spermatozoa increased $(P<0.05)$ and bacterial count decreased $(\mathrm{P}<0.05)$ in post-equilibrated and post-thawed semen extended with $0.5 \%$ soy-lecithin. These results reflected in the highest conception rate $(66.7 \%)$ of buffalo cows inseminated with semen containing $05 \%$ soy-lecithin compared with $53.3 \%$ in semen containing egg yolk (control).

In conclusion, egg yolk could be replaced by soy-lecithin in tris-based extender at a level of $0.5 \%$ to increase fertilizing capacity of cryopreserved buffalo semen.
\end{abstract}

Keywords: Buffalo, frozen semen, sperm, bacterial count, fertility.

\section{INTRODUCTION}

Buffalo semen is routinely cryopreserved in extender with regular ingredient egg yolk as a non-permeable cryoprotectant that maintains postthaw quality and fertilizing ability of the spermatozoa (Akhter et al., 2008). Extenders free of animal protein have been tested by Bousseau et al. (1998), because the use of egg yolk associated with sanitary risks may contribute in lower fertility of cryopreserved semen directly through deteriorating the semen quality by producing harmful metabolites and toxins or indirectly through local infection leading to abortion (Akhter et al., 2008; Althouse, 2008). Also, egg yolk in extender can reduce the respiration and motility of ram spermatozoa (Watson and Martin, 1976). Egg yolk and/or milk represent a risk of contamination if microorganisms, such as bacteria and fungi, are present in the fresh product. Such contamination can release endo- toxins that reduce the fertilization capacity of sperm (Bittencourt et al., 2008). Furthermore, high density lipoproteins (HDLs) in egg yolk are one factor that decreases the quality of semen by causing efflux of cholesterol from the sperm plasma membrane and resulted in change in fluidity that increase the sensitivity to cold shock (Amirat et al., 2005). However, improvement in the semen quality occurs after supplementing low density lipoproteins (LDLs) 
extracted from hen egg yolk (Akhter et al., 2011a). The main effective component of egg yolk is LDLs fraction like lecithin, which protects the membrane phospholipids integrity during cryopreservation (Moussa et al., 2002; Amirat et al., 2004).

A viable alternative to replace the components of animal origin in extenders for freezing semen is soy bean lecithin, a phospholipid that is the main component of the phosphate fraction of egg yolk and soy bean (Campbell and Farrel, 2007). Soybean lecithin may reduce the sanitary risks and improvement in semen quality and fertility (Althouse, 2008; Andrabi, 2009; Akhter, et al., 2011b). In this respect, Amirat et al. (2005) reported higher sperm numbers with functionally intact acrosome cryopreserved in soy-lecithin-based extender like Biociphos Plus as compared to an egg yolkbased extender like Triladyl. Bioxcell is the only soy-lecithin-based extender evaluated for freezability and fertility of buffalo bull semen. Also, Akhter et al. (2012) reported soy-lecithin in extender improves the freezability and fertility of buffalo bull spermatozoa and can be used as an alternate to egg yolk in cryopreservation of buffalo semen.

In Egypt, buffalo semen is commonly preserved in milk, tris-egg yolk or egg yolk-citrate extenders. These extenders contain additives of animal origin (egg yolk and/or milk) which may pose a potential risk of microbial contamination (Thibier and Guerin et al., 2000) leading to deteriorate in semen quality (Akhter et al., 2008) and causing reproductive problems and low fertility rate in females (Andrabi et al., 2001; Akhter et al., 2007). Therefore, a well defined and pathogen-free substitute for egg yolk (nonanimal origin) would be more suitable for extenders used for semen (Stradaioli et al., 2007).

A number of commercially available extenders containing a substitute for egg yolk have been used for the preservation of bovine, ovine and caprine semen by a number of workers. The examples are of AndroMed® (Muino et al., 2007), Biociphos plus $\AA^{8}$ (Amirat et al., 2005), and Bioxcell® (Celeghini et al., 2008). Preservation of bull (Hansen et al., 2005; Stradaioli et al., 2007; Celeghini et al., 2008) and ram (Gil et al., 2003a,b) spermatozoa in soylecithin based extender Bioxcell囚 maintained the sperm quality and roduced acceptable fertility rates (Gil et al., 2003b).

Therefore, the present study was designed to evaluate the effect of egg yolk replacement with alternative cryoprotectants such as plant-derived lecithin from soy bean on sperm characteristics (motility, livability and acrosome status), bacterial content and fertility of cryopreserved buffalo semen.

\section{MATERIALS AND METHODS}

This study was conducted at the International Livestock Management Training Center (ILMTC), Sakha, belonging to the Animal Production Research Institute, Agricultural Research Center, Ministry of Agriculture.

Semen collection:

Following sexual preparation, semen was collected by artificial vagina from five sexually mature buffalo bulls (about four years old). All bulls 
were healthy and clinically free of external and internal parasites. Palpation of the external genitalia showed that they were typically normal. The testicular tone was glandular, almost equal in size and moved freely up and down within the scrotal pouches.

Semen was collected twice weekly from each bull and immediately held in a water bath at $37^{\circ} \mathrm{C}$ before transferred to the lab. Ejaculates having good mass motility $(\geq 70 \%)$ were pooled for each collection day for 10 weeks. On each collection day, semen was pooled and divided into 4 parts; the first was diluted with tris-egg yolk extender (control), while others were diluted with tris soy-lecithin at levels of $0.5,1.0$ and $2 \%$. Average total bacterial count in fresh semen was $3.12 \times 10^{4} \mathrm{cfu}$.

\section{Experimental extenders:}

Tris extender was prepared from $1.675 \mathrm{~g}$ citric acid, $3.025 \mathrm{~g}$ tris(hydroxymethyl-aminomethane), $0.75 \mathrm{~g}$ glucose, $7.0 \%$ glycerol and $15 \%$ egg yolk (0\%soy-lecithin, control extender). While, soy-lecithin (Sigma, St. Louis, MO, USA) was substituted egg yolk by levels of $0.5,1$ and $2 \%$ (treatment extenders). . Amounts of $0.25 \mathrm{~g}$ lincospectin and $0.005 \mathrm{~g}$ streptomycin were added to all extenders. All contents were thoroughly dissolved in bi-distilled water up to $100 \mathrm{ml}$.

\section{Semen freezing:}

Pooled ejaculates were diluted at a rate of 1:20. The tris-egg yolk and tris- lecithin extenders were gently mixed and wormed up to $37^{\circ} \mathrm{C}$ in a water bath during semen extension and cooled gradually in a refrigerator at $5^{\circ} \mathrm{C}$ for 4 hours as an equilibration period.

At the end of equilibration period, the extended semen was loaded in $0.25 \mathrm{ml}$ French straws, contained $20 \times 10^{6}$ motile sperm, using a semen filling machine, during filling in the straws extended semen was kept in ice water bath to keep its temperature at $5^{\circ} \mathrm{C}$. Straws were transferred into liquid nitrogen canister and located horizontally in static nitrogen vapor $4 \mathrm{~cm}$ above the surface of liquid nitrogen for 10 minutes, then the straws were placed vertically in a metal canister and immersed completely in liquid nitrogen container for storage at $-196^{\circ} \mathrm{C}$.

Frozen semen was thawed by dipping the frozen straws into a water bath at $37^{\circ} \mathrm{C}$ for 30 seconds.

\section{Semen evaluation:}

Percentages of motility, livability, intact acrosome of spermatozoa and bacterial count were determined using a hot microscope stage adjusted at $37^{\circ} \mathrm{C}$ in post-diluted, post- equilibrated and post-thawed semen. Percentage of motile spermatozoa (progressive motility) was assessed using research microscope with warmed stage $\left(37^{\circ} \mathrm{C}\right)$ under the high power magnification (x400) according to Amman and Hammerstedt (1980). Sperm livability percentage was determined using eosin and nigrosin mixture stain according to Hackett and Macpherson (1965). Live spermatozoa (unstained ones) and dead spermatozoa (stained ones) were counted in field of a total of 200 spermatozoa. Then percentage of live spermatozoa was calculated. Percentage of intact acrosome was conducted as indicated by Watson (1975). 


\section{Total aerobic bacterial counts:}

Total bacterial counts in semen samples were determined by surface plate method (Azawi and Ismaeel, 2012) in diluted, post-equilibrated and post-thawed semen. These plates were incubated at $37^{\circ} \mathrm{C}$ for $48 \mathrm{~h}$ and average colony count was expressed as cfu (colony forming unit)/ml.

\section{Fertility trail:}

Total of 60 buffalo cows in heat were divided into 4 groups (15 in each). Buffalo cows in each group were inseminated with frozen/thawed semen extended with different types of extenders $(0,0.5,1.0$. and $2.0 \%$ soylecithin). Frozen semen of each treatment was thawed at $37^{\circ} \mathrm{C}$ for 30 seconds and immediately post-thawing, gun of insemination was used to artificial insemination. Pregnancy diagnosis was performed 50 day-post insemination using rectal palpation.

\section{Statistical analysis:}

Results were statistically analyzed according to Snedecor and Cochran (1982) using SAS system (2004). The differences among means were tested using Duncan's new multiple range test (Duncan, 1955). The percentage values were subjected to arcsine transformation before performing the analysis of variance. Means were presented after being recalculated from the transformed.

\section{RESULTS}

\section{Sperm characteristics of diluted semen:}

Results presented in Table 1 showed that significant $(P<0.05)$ differences in the percentage of livability and intact acrosome in diluted semen, while sperm motility was slightly increased in 0.5 and $1 \%$ soy-lecithin, but the difference was not significant. It is of interest to note that sperm livability and intact acrosome percentages significantly $(P<0.05)$ reduced at high soy-lecithin level (2\%) when compared to control. Generally, extension of semen with soy-lecithin at a level of $0.5 \%$ showed the highest percentages of motility, livability and intact acrosome as compared to other soy-lecithin levels and egg yolkextenders.

Table 1: Effect of soy-lecithin on sperm characteristics in diluted semen.

\begin{tabular}{|l|c|c|c|c|}
\hline \multirow{2}{*}{$\begin{array}{l}\text { Sperm } \\
\text { characteristics (\%) }\end{array}$} & 15\% egg & \multicolumn{3}{|c|}{ Level of soy-lecithin } \\
\cline { 3 - 5 } & yolk & $\mathbf{0 . 5 \%}$ & $\mathbf{1 \%}$ & $\mathbf{2 \%}$ \\
\hline Progressive motility & $75.50 \pm 1.57$ & $77.00 \pm 1.11$ & $76.50 \pm 1.07$ & $73.50 \pm 1.50$ \\
\hline Livability & $76.50 \pm 1.10^{\mathrm{a}} \mathrm{b}$ & $78.70 \pm 0.70^{\mathrm{a}}$ & $77.20 \pm 1.22^{\mathrm{ab}}$ & $74.20 \pm 1.31^{\mathrm{b}}$ \\
\hline Intact acrosome & $78.80 \pm 1.13^{\mathrm{ab}}$ & $82.10 \pm 1.22^{\mathrm{a}} 81.00 \pm 1.01^{\mathrm{ab}}$ & $76.90 \pm 1.55^{\mathrm{b}}$ \\
\hline
\end{tabular}

\section{Sperm characteristics of post-equilibrated semen:}

Data in Table 2 showed that pronounced effect of soy-lecithin level on sperm characteristics in post-equilibrated semen. Only, extension of semen with soy-lecithin at a level of $0.5 \%$ showed significantly $(P<0.05)$ the highest percentages of motility, livability and intact acrosome in post- 
equilibrated semen when compared with other extenders. However, increasing level of soy-lecithin to 1.0 or $2.0 \%$ did not improve these characteristics, but still nearly similar to the control extender. In the same time, all sperm characteristics in $1 \%$ soy-lecithin extender were higher than in control, but the differences were not significant.

Table 2: Effect of soy-lecithin on sperm characteristics in postequilibrated semen.

\begin{tabular}{|l|r|c|c|c|}
\hline \multirow{2}{*}{$\begin{array}{l}\text { Sperm characteristic: } \\
\text { (\%) }\end{array}$} & \multirow{2}{*}{$\%$ egg yolk } & \multicolumn{3}{|c|}{ Soy-lecithin } \\
\cline { 3 - 5 } & & $\mathbf{0 . 5 \%}$ & $\mathbf{1 \%}$ & $\mathbf{2 \%}$ \\
\hline Progressive motility & $60.00 \pm 1.49^{\mathrm{b}}$ & $71.00 \pm 1.25^{\mathrm{a}}$ & $64.50 \pm 2.17^{\mathrm{b}}$ & $61.00 \pm 1.80^{\mathrm{b}}$ \\
\hline Livability & $62.60 \pm 1.64^{\mathrm{b}}$ & $72.80 \pm 1.37^{\mathrm{a}}$ & $66.10 \pm 2.12^{\mathrm{b}}$ & $62.80 \pm 1.65^{\mathrm{b}}$ \\
\hline Intact acrosome & $64.20 \pm 1.71^{\mathrm{b}}$ & $76.80 \pm 1.23^{\mathrm{a}}$ & $68.90 \pm 1.85^{\mathrm{b}}$ & $64.70 \pm 1.64^{\mathrm{b}}$ \\
\hline
\end{tabular}

$a$ and $b$ : Means denoting within the same row with different superscripts are significantly different at $P<0.05$.

\section{Sperm characteristics of post-thawed semen:}

Results presented in Table 3 showed that various effects of soylecithin level on sperm characteristics in post-thawed semen. Also, semen extension with soy-lecithin at levels of $0.5 \%$ showed significantly $(P<0.05)$ the highest percentages of motility, livability and intact acrosome in post-thawed as found in post-equilibrated semen. While these parameters were reduced by increasing level of soy-lecithin to $2.0 \%$ as compared to the control extender.

Table 3: Effect of soy-lecithin on sperm characteristics in post-thawed semen.

\begin{tabular}{|l|c|c|c|c|}
\hline \multirow{2}{*}{$\begin{array}{l}\text { Sperm } \\
\text { characteristics (\%) }\end{array}$} & \multirow{2}{*}{$\mathbf{1 5 \%}^{2}$ egg yolk } & \multicolumn{3}{|c|}{ Soy-lecithin } \\
\cline { 2 - 5 } & & $\mathbf{0 . 5 \%}$ & $\mathbf{1 \%}$ & $\mathbf{2 \%}$ \\
\hline Progressive motility & $47.00 \pm 1.53^{\mathrm{bc}}$ & $60.50 \pm 1.38^{\mathrm{a}}$ & $50.50 \pm 1.74^{\mathrm{b}} 45.00 \pm 1.29^{\mathrm{c}}$ \\
\hline Livability & $50.10 \pm 1.35^{\mathrm{bc}}$ & $61.30 \pm 1.37^{\mathrm{a}}$ & $51.70 \pm 1.78^{\mathrm{b}} 46.10 \pm 1.52^{\mathrm{c}}$ \\
\hline Intact acrosome & $52.60 \pm 1.14^{\mathrm{b}}$ & $63.50 \pm 1.65^{\mathrm{a}}$ & $52.80 \pm 1.87^{\mathrm{b}} 49.60 \pm 1.12^{\mathrm{b}}$ \\
\hline a and b: Means denoting within the same row with different superscripts are significantly \\
different at $\mathrm{P}<0.05$.
\end{tabular}

Bacterial count in diluted, post-equilibrated and post-thawed semen: Results presented in Table 4 showed significant $(P<0.05)$ improvement of various levels of soy-lecithin as compared to egg yolk in bacterial count in diluted, post-equilibrated and post-thawed semen.

Table 4: Effect of soy-lecithin on bacterial count (cfu/ml semen) in diluted, post-equilibrated and post-thawed semen.

\begin{tabular}{|l|c|c|c|c|}
\hline \multirow{2}{*}{ Semen } & \multirow{2}{*}{$\mathbf{1 5 \%}$ egg yolk } & \multicolumn{3}{|c|}{ Soy-lecithin } \\
\cline { 3 - 5 } & & $\mathbf{0 . 5 \%}$ & $\mathbf{1 \%}$ & $\mathbf{2 \%}$ \\
\hline Diluted & $477.40 \pm 9.93^{\mathrm{a}}$ & $103.20 \pm 7.30^{\mathrm{b}}$ & $102.60 \pm 1.44^{\mathrm{b}}$ & $105.00 \pm 3.18^{\mathrm{b}}$ \\
\hline Post-equilibration & $391.40 \pm 6.19^{\mathrm{a}}$ & $98.80 \pm 0.86^{\mathrm{b}}$ & $98.20 \pm 2.48^{\mathrm{b}}$ & $99.80 \pm 1.77^{\mathrm{b}}$ \\
\hline Post- thawed & $126.40 \pm 11.79^{\mathrm{a}}$ & $71.40 \pm 2.18^{\mathrm{b}}$ & $85.80 \pm 3.81^{\mathrm{b}}$ & $92.60 \pm 8.48^{\mathrm{b}}$ \\
\hline a and b: Means denoting within the same row with different superscripts are significantly
\end{tabular}
different at $P<0.05$. 


\section{Fertility trail:}

Data in Table 5 showed that conception rate of was higher for buffalo cows inseminated with semen extended with $0.5 \%$ soy-lecithin $(66.7 \%)$ than $2 \%$ soy-lecithin extender (46.7\%) and control (53.3\%). Such result was associated with sperm characteristics in post-thawed semen.

Table 5: Effect of level of soy-lecithin on conception rate of buffalo cows.

\begin{tabular}{|l|c|c|c|c|}
\hline \multirow{2}{*}{ Item } & \multirow{2}{*}{$\mathbf{1 5 \%}$ egg yolk } & \multicolumn{3}{|c|}{ Soy-lecithin } \\
\cline { 3 - 5 } & & $\mathbf{0 . 5} \%$ & $\mathbf{1 \%}$ & $\mathbf{2 \%}$ \\
\hline Inseminated animals & 15 & 15 & 15 & 15 \\
\hline Non-conceived animals & 7 & 5 & 7 & 8 \\
\hline Conceived animals & 8 & 10 & 8 & 7 \\
\hline Conception rate (\%) & 53.3 & 66.7 & 53.3 & 46.7 \\
\hline
\end{tabular}

$a$ and $b$ : Means denoting within the same row with different superscripts are significantly different at $\mathrm{P}<0.05$.

\section{DISCUSSION}

Egg yolk is routinely used as a non-permeable cryoprotectant for trisbased extenders, which provide protection against thermal shock and preserve sperm motility, and maintains acrosomal as well as mitochondrial integrity (Moustacas et al., 2011). Although, egg yolk is reported to have cryoprotectant antagonists, inconsistent composition, HDLs and egg yolk granules that interfere with sperm motility (Ansari et al., 2010).

According to the obtained results in this study, percentages of livability and intact acrosome were improved in diluted semen, meanwhile all sperm parameters studied were improved in post-equilibrated and postthawed semen extended with $0.5 \%$ soy-lecithin as compared to other levels of soy-lecithin extenders. In according with the present results, several authors reported that using soy-lecithin based extender (Biociphos Plus $\AA$ ) have higher percentage of sperm motility as compared to tris-egg yolk based extender in frozen-thawed bovine semen (Gil et al., 2000; Moussa et al., 2002; Amirat et al., 2004, 2005; Stradaioli et al., 2007). Also, studies by Aires et al. (2003) have also reported a significant increase in sperm motility in post-thawed semen extended with soy-lecithin based extender (AndroMed(B) as compared to egg yolk extender.

In the present study, sperm viability percentage was found to be higher with $0.5 \%$ soy-lecithin in diluted, post-equilibrated and post-thawed semen. Similarly, Amirat et al. (2005) reported higher viable sperms in soylecithin based extender (Biociphos Plus $\AA$ ) as compared to egg yolk based extender. Also, in studies on bovine spermatozoa preserved with soy-lecithin based extenders (AndroMed $\AA$, Biociphos Plus $\AA$ and Bioxcell ${ }^{\circledR}$ ), higher percentage of live spermatozoa was recorded as compared to egg yolk based extender (Nehring and Rothe, 2003).

The present study on the percentage of intact acrosome spermatozoa supported the highest results of sperm progressive motility and livability. The obtained percentage of intact acrosome spermatozoa increased 
with increasing percentages of sperm motility and livability during different cryopreservation processes in semen extended with $0.5 \%$ soy-lecithin (Anzar and Graham, 1993). In contrast to the present results, Akhter et al. (2010) found that using Bioxcell did not improve membrane integrity of buffalo spermatozoa as compared to milk extender.

The observed improvement in sperm parameters in frozen/thawed semen with soy-lecithin based extender at a level of $0.5 \%$ in this study was mainly attributed to that LDLs protect the sperm during freezing while HDLs contents of egg yolk deteriorate the quality of the sperm (Amirat et al., 2005) and deleterious effect of egg yolk results in reduction of respiration and sperm motility (Pace and Graham, 1974; Watson and Martin, 1975). In this respect, Gil et al. (2003 a\&b) proved that non-animal substitute of milk or egg yolk in an extender results in improved bacteriological qualities which protect the sperm from toxins produced by bacteria in the semen. This phenomenon was supported in the present study, where bacterial count in frozen/thawed semen extended with all levels of soy-lecithin based extender significantly reduced as compared to egg yolk based extender (Control). Milk and egg yolk in extender can alter the sperm chromatin structure which result in poor post-thaw viability (Gil et al., $2003 \mathrm{a \& b}$ ). Moreover, the quality of the egg yolk is not consistent and has deleterious effect for sperm viability (MullerSchlosser, 2001). Some factors in egg yolk are reported to destabilize the sperm plasma membrane during storage (Watson and Martin, 1976; Smith et al., 1979). In this line, Amirat et al. (2005) reported $30-80 \%$ sperm acrosomal damage after one hour of dilution in egg yolk based extender (Triladyl $\left.\AA^{\circ}\right)$, and suggested that higher calcium ions present in the egg yolk cause acrosomal destruction especially below $30^{\circ} \mathrm{C}$, because of higher rate of calcium ions infusion. The component of egg yolk, which gives protection to membrane phospholipid integrity during cryopreservation, is LDLs also known as lecithin (Moussa et al., 2002; Amirat et al. 2004; Andrabi et al., 2008).

The number of viable sperms per insemination dose after cryopreservation significantly affects fertility rates in the field (Andrabi et al., 2006). The evaluation of plasma membrane integrity is of significance as it controls the metabolic exchanges with the surrounding medium (Silva and Gadella, 2006) and a biochemically active plasmalemma is required for the process of capacitation, acrosome reaction and the oocyte penetration (Jeyendran et al., 1984). Freeze-thawing processes impair the plasma membrane functions of buffalo bull spermatozoa (Anzar et al., 2010). The presence of normal acrosome on a spermatozoon is essential for the acrosomal reaction required to facilitate fertilization (Thomas et al., 1997) and its assessment can be an effective tool to predict the fertilizing ability of buffalo bull spermatozoa. The damage to bio-membrane system that mostly occurs during cryopreservation reduced sperm motility and fertilizing ability of frozen-thawed spermatozoa (Ansari et al., 2010).

These findings were supported in the present study, whereas semen extended with $0.5 \%$ soy-lecithin extender exhibiting the highest percentage of intact acrosome spermatozoa revealed the highest conception rate $(66.7 \%)$ in comparing with other treatments. A high correlation between the percentage of intact acrosome and fertility of frozen bovine spermatozoa was reported 
after 2 and $4 \mathrm{~h}$ of post-thaw incubation (Saacke and White, 1972). In accordance with the obtained results, soy-lecithin extender may have been incapable of improving the fertility of cryopreserved buffalo semen as it is developed for bovine semen and buffalo sperm have different physiology compared with cattle bull spermatozoa (Andrabi, 2009). It is pertinent to mention that LDLs (from hen egg yolk) replacing egg yolk in extender improved the fertility of frozen buffalo semen (Akhter et al., 2011a).

It is noteworthy to mention that HDLs of egg yolk interact with bovine seminal plasma proteins and accelerate the sperm capacitation, while the LDLs interact with seminal plasma proteins (Manjunath et al., 2002), decrease the efflux of cholesterol and phospholipids from the spermatozoa membrane and prevent premature capacitation and subsequent acrosome reaction (Bergeron et al., 2004). It is to believe that HDLs in egg yolk are responsible for capacitation and simultaneous acrosome reaction (Anton et al., 2003).

\section{CONCLUSION}

In conclusion, soy-lecithin at a level of $0.5 \%$ (as the lipid/lipoprotein plant source) can be an alternative to egg yolk as an animal product in tris extender preparation for cryopreserved buffalo semen to increase fertilizing capacity of cryopreserved buffalo semen.

\section{REFERENCES}

Aires, V.A.; Hinsch, K.D.; Mueller-Schloesser, F.; Bogner, K.; MuellerSchloesser, S. and Hinsch, E. (2003). In vitro and in vivo comparison of egg yolk-based and soybean lecithin-based extenders for cryopreservation of bovine semen. Theriogenology, 60:269-79.

Akhter, S.; Ansari, M.S.; Andrabi, S.M.H.; Ullah, N.and Qayyum, M. ( 2008). Effect of Antibiotics in Extender on Bacterial and Spermatozoal Quality of Cooled Buffalo (Bubalus bubalis) Bull Semen. Reprod. Dom. Anim. 43: 272-278.

Akhter, S.; Ansari, M.S.; Andrabi, S.M.H; Rakha, B.A; Ullah, N. and Khalid, M.(2012). Soya-lecithin in Extender Improves the Freezability and Fertility of Buffalo (Bubalus bubalis) Bull Spermatozoa. Reprod. Dom. Anim., 47: 815-819.

Akhter, S.; Ansari, M.S.; Rakha, B. A.; Andrabi, S.M.H.; Khalid, M. and Ullah, N. (2011a). Effect of low density lipoproteins in extender on freezability and fertility of buffalo (Bubalus bubalis) bull. Theriogenology, 76: 759764.

Akhter, S.; Ansari, M.S.; Rakha, B.A.; Andrabi, S.M.H; lqbal, S. and Ullah, N. (2010) Cryopreservation of buffalo (Bubalus bubalis)semen in Bioxcell extender. Theriogenology, 74: 951-955.

Akhter, S.; Ansari, M.S.; Rakha, B.A.; Ullah, N.; Andrabi, S.M.H.and Khalid, M. (2011b). In vitro evaluation of liquid-stored buffalo semen at $5^{\circ} \mathrm{C}$ diluted in soya lecithin based extender (Bioxcell), tris-citric egg yolk, skim milk and egg yolk-citrate extenders. Reprod. Domest. Anim., 46: 45-49. 
Akhter, S.; Sajjad, M.; Andrabi, S.M.H.; Ullah, N. and Qayyum, M. (2007). Effect of antibiotics in extender on fertility of liquid buffalo bull semen. Pakistan Vet. J., 27: 13-16.

Althouse, G.C. (2008). Sanitary procedures for the production of extended semen. Reprod. Domest. Anim., 43: 374-378.

Amann. R.P. and Hammersted, R. H. (1980).Validation of system for computerized measurement of spermatozoal velocity and percentage of motile sperm. Biol. Reprod., 23:647-656.

Amirat, L.; Anton, M.; Tainturier, D.; Chatagnon, G.R.; Battut, I. and Courtens, J.L. (2005). Modifications of bull spermatozoa induced by three extenders: biociphos, low density lipoprotein and Triladyl, before, during and after freezing and thawing. Reprod., 129: 535-543.

Amirat, L.; Tainturier, D.; Jeanneau, L.; Thorin, C.; Gerard, O.; Courtens, J.L. and Anton, M. (2004).Bull semen in vitro fertility after cryopreservation using egg yolk LDL: a comparison with Optidyl1,a commercial egg yolk extender. Theriogenology, 61:895-907.

Andrabi, S.M.H. (2009). Factors affecting the quality of cryopreserved buffalo (Bubalus bubalis) bull spermatozoa. Reprod. Domest. Anim., 44:552569.

Andrabi, S.M.H.; Ahmad, N.; Abbas, A. and Anzar, M. (2001). Effect of two different antibiotic combinations on fertility of frozen buffalo and Sahiwal bull semen. Pakistan Vet. J., 21: 166-169.

Andrabi, S.M.H.; Ansari, M.S.; Ullah, N., Anwar, M.; Mehmood, A. and Akhter, S. (2008). Duck egg yolk in extender improves the freezability of buffalo bull spermatozoa. Anim. Reprod. Sci., 104:427-433.

Andrabi, S.M.H.; Siddique, M.; Ullah, N. and Khan, L.A. (2006). Effect of two different antibiotic combinations on fertility of frozen buffalo and sahiwal semen. Pakistan Vet. J. 26, 17-19.

Ansari, M.S.; Rakha, B.A.; Andrabi, S.M.H; Akhter, S.(2010). Usefulness of powderedand fresh egg yolk for cryopreservation of Zebu bull spermatozoa. Reprod. Biol., 10:235-240.

Anton, M.; Martinet, V.; Dalgalarrodo, M.; Beaumal, V.; David-Briand, E. and Rabesona, H. (2003). Chemical and structural characterization of lowdensity lipoproteins purified from hen egg yolk. Food Chem., 83:175183.

Anzar, M. and Graham, E.F. (1993). Filtration of bovine semen. I. Development of a Sephadex-ion exchange filter. Anim. Reprod. Sci., 31: 187-195.

Anzar, M.; Rasul, Z.; Ahmed, T.A. and Ahmad, N.(2010). Response of buffalo spermatozoa to low temperatures during cryopreservation. Reprod. Fertil. Dev., 22: 871-880.

Azawi, O. I. and Ismaeel, M. A. ( 2012). Influence of addition of different antibiotics in semen diluent on viable bacterial count and spermatozoal viability of Awassi ram semen. Vet. World, 5:75-79.

Bergeron, A.; Crete, M-H. and Manjunath, P. (2004) Low-density lipoproteins fraction from hen's egg yolk decreases the binding of the major proteins of bovine seminal plasma to sperm and prevents lipid efflux from the sperm membrane. Biol. Reprod., 70: 708-717. 
Bittencourt, R.F.; Ribeiro Filho, A.L.; Chalhoub, M.; Alves, S.G.G.; Vasconcelos, M.F.; Biscarde, C.E.; Leal, L.S. and Oba, E. (2008). Efeito de um quelante de cálcio, um detergente e da lecitina de soja sobre a qualidade dosêmen caprino congelado-descongelado. Braz. J. Vet. Res. Anim. Sci., 45:305-312.

Bousseau, S.; Brillard, JP.; Guienne, M.; Guerin, B., Camus A. and Lechat, M. (1998). Comparison of bacteriological qualities of various egg yolk sources and the in vitro and in vivo fertilizing potential of bovine semen frozen in egg yolk or lecithin-based diluents. Theriogenology, 50:699706.

Campbell, M.K. and Farrel, S.O. (2007). Lipídeos e proteínas estão associados a membranas biológicas. In: Campbell, M.K., Farrel, S.O. (Eds.), Bioquímica., $5^{\text {th }}$ ed. Thomson Learning, São Paulo, p. p202 (Cap. 8).

Celeghini, E.C.C.; Arruda, R.P.D.; Andrade, A.F.C.D.; Nascimento, J.; Raphael, C.F. and Roderigues, P.H.M.(2008). Effects that bovine sperm cryopreservation using two different extenders has on sperm membranes and chromatin. Anim. Reprod. Sci., 104: 119

Duncan, D.B. (1955). Multiple Range and Multiple F. Test Biometrics, 11: 142.

Gil, J.; Januskausks, A.; Haard, M.C.; Haard, M.G.M.; Johanisson, A., Soderquist, L. and Rodriguez-Martinez, H. (2000). Functional sperm parameters and fertility of bull semen extended in Biociphos Plus. Reprod. Dom. Anim., 35: 69-77.

Gil, J.; Lundeheim, N.; Soderquist, L.; Rodriguez-Martinez, H. (2003a). Influence of extender, temperature, and addition of glycerol on postthaw sperm parameters in ram semen. Theriogenology, 59: 12411255.

Gil, J.; Rodriguez-Irazoqui, M.; Lundeheim, N., Söderquist, L. and RodríguezMartínez, H. (2003b). Fertility of ram semen frozen in Bioexcell $\AA^{\circ}$ and used for cervical artificial insemination. Theriogenology, 59: 11571170.

Hackett, A.J. and Macpherson, J.W. (1965). A method for differential staining of bovine spermatozoa after extension in sterile milk. Can. Vet. J., 6: 117-120.

Hansen, G.B.B.; Morris, I.D.; Ersboll, A.K.; Greve, T. and Christensen, P.(2005). DNA integrity in sexed bull sperm assessed by neutral Comet assay and sperm chromatin structure assay. Theriogenology, 63:1789-1802.

Jeyendran, R.S.; Van Der Ven, H.H.; Perez-Pelaez, M.; Crabo, B.G. and Zaneveld, L.J.D.( 1984). Development of an assay to assess the functional integrity of the human sperm membrane and its relationship to other semen characteristics. J. Reprod. Ferti., 70: 219-228.

Manjunath, P.; Nauc, V.; Bergeron, A. and Menard, M.(2002). Major proteins of bovine seminal plasma bind to the low-density lipoprotein fraction of hen's egg yolk. Biol. Reprod., 67: 1250-1258. 
Moussa, M.; Matinet, V.; Trimeche, A.; Tainturier, D. and Anton, M. (2002). Low density lipoproteins extracted from hen egg yolk by an easy method: cryoprotective effect on frozen-thawed bull semen. Theriogenology, 57:1695-706.

Moustacas, V.S.; Zaffalon, F.G.; Lagares, M.A.; Loaiza-Eccheverri ,A.M.; Varago, F.C.; Neves M.M.; Heneine, L.G.D.; Arruda, R.P. and Henry, M. (2011). Natural, but not lyophilized, low density lipoproteins were an acceptable alternative to egg yolk for cryopreservation of ram semen. Theriogenology, 75: 300-307.

Muino, R.; Fernandez, M. and Pen, A.I.(2007). Post-thaw Survival and Longevity of Bull Spermatozoa Frozen with an Egg Yolk-based or Two Egg Yolk-free Extenders after an Equilibration Period of 18h. Reprod. Dom. Anim., 42: 305-311.

Muller-Schlosser, F.; Aires, V.; Hinsch, E. and Hinsch, K.D.(2001). Evaluation of the quality of a new generation of egg yolk free semen diluters for cryopreservation of bovine semen. $34^{\text {th }}$ Conference on physiology and pathology of reproduction, Giessen.

Nehring, H. and Rothe, L. (2003). Insemination of cryopreserved bull semen portions with reduced sperm numbers after dilution with two egg yolkfree extenders. Proc. 15 $5^{\text {th }}$ Europ. Al Vets Meet. Budapest Hungary, 1423.

Pace, M.M., Graham, E.F., (1974).Components in egg yolk which protect bovine spermatozoa during freezing. J. Anim. Sci., 39: 1144-1149.

Saacke, R.G. and White, J.M.(1972). Acrosomal cap maintenance and fertility of frozen bovine semen. J. Anim. Sci., 35: 253.

SAS (2004). SAS user Guide: Statistics SAS. Inc., Cary, NC.

Silva, P.F.N. and Gadella, B.M.(2006). Detection of damage in mammalian sperm cells. Theriogenology, 65: 958-978.

Smith, R.L.; Berndston, W.E.; Unal, M.B. and Pickett, B.W.( 1979). Influence of percent egg yolk during cooling and freezing on survival of bovine spermatozoa. J. Dairy Sci. 62, 1297-1303.

Snedecor, G.W. and Cochran, G.W.(1982). Statistical Methods. $7^{\text {th }}$ ed. The lowa State Univ. Press lowa, Ames., USA.

Stradaioli, G.; Noro, T.; Sylla, L. and Monaci, M.(2007). Decrease in glutathione $(\mathrm{GSH})$ content in bovine sperm after cryopreservation: comparison between two extenders. Anim. Reprod. Sci., 67: 12492155.

Thibier, M. and Guerin, B.(2000). Hygienic aspects of storage and use of semen for artificial insemination. Anim. Reprod. Sci., 62: 233-251.

Thomas, C.A.; Garner, D.L.; de-Jarnette, J.M. and Marshall, C.E.(1997). Fluorometric assessment of acrosomal integrity and viability in cryopreserved bovine spermatozoa. Biol. Reprod., 45: 880-887.

Watson, P.F. (1975). Use of a Giemsa stain to detect changes in acrosomes of frozen ram spermatozoa. Vet. Re., 97: 12-15.

Watson, P.F. and Martin, C.A.(1975). The influence of some fractions of egg yolk on the survival of ram spermatozoa at $5^{\circ} \mathrm{C}$. Australian J. Bio. Sci., 28:145-152. 


\section{El-Sherbieny, M.A.}

Watson, P.F. and Martin, I.C. (1976) Artificial insemination of sheep: the effect of semen diluents containing egg yolk on the fertility of ram semen. Theriogenology, 6: 927-935.

العائد من استبدال صفار البيض بالليسيثين الصويا علي خصيائص الحيوان المئوي الئوي والعد

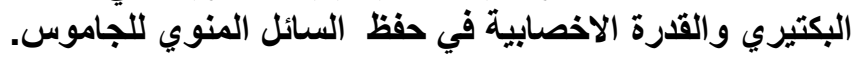
معمد عبد الجواد الثربيني معهد بحوث الأنتاج الحيو الني- مركز البحوث الزراعية ـ وزارة الزراعة.

تم استخدام ليسيثين فول الصويا في مخفف السائل المنوي بديلا عن صفار البيض.الهدف

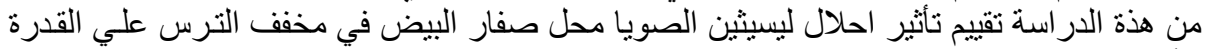

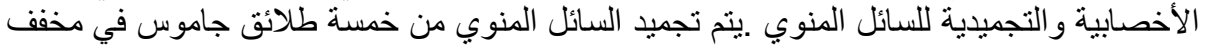

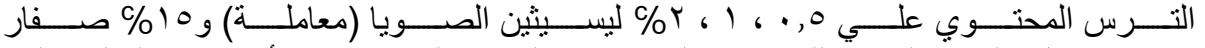

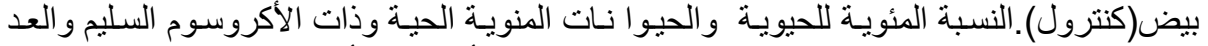

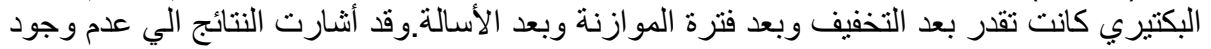

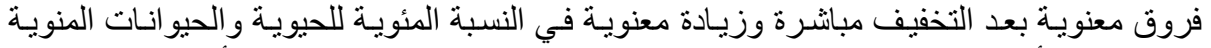

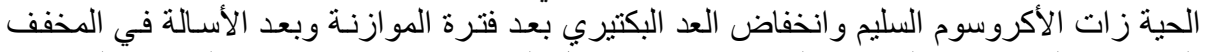

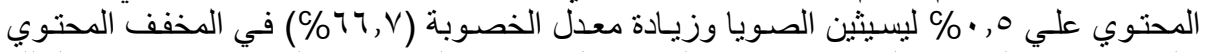

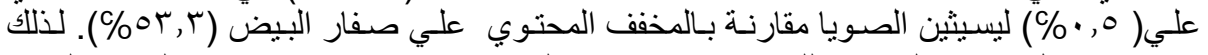

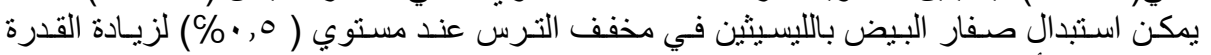
التجميدية و الأخصابية للسائل المنوي للجاموس. 